\title{
Effect of Incorporation of Corn Bran, Dried Carrot Pomace and Dried Tomato Pomace on Quality Attributes of Chicken Nuggets
}

\author{
Sanjay Yadav ${ }^{1 *}$, A.K. Pathera ${ }^{2}$, R.U. Islam ${ }^{3}$ and Ashok Malik ${ }^{1}$ \\ ${ }^{1}$ Department of Livestock Products Technology, College of Veterinary Sciences, Lala Lajpat Rai University of Veterinary and \\ Animal Sciences, Hisar (Haryana), INDIA \\ ${ }^{2}$ School of Bioengineering and Food Technology, Shoolini University, Solan, U.P., INDIA \\ ${ }^{3}$ Department of Bioengineering, Integral University, Lucknow, U.P., INDIA \\ *Corresponding author: S Yadav; E mail: syadav_lpt123@yahoo.co.in
}

Received: 06 Mar., 2020

Revised: 29 March, 2020

Accepted: 31 March, 2020

\begin{abstract}
A study was conducted to improve dietary fibre content of chicken nuggets by incorporating corn bran (CB), dried carrot pomace (DCP) and dried tomato pomace (DTP) as dietary fibre sources. Lean meat was replaced with each dietary fibre source at 3\%, $6 \%$ and $9 \%$ level. One product from each fibre source was selected on the basis of sensory evaluation. Sensory acceptability of 3\% fibre treated nuggets was comparable with control and further increase in fibre level resulted in a decline in sensory acceptability. All CB and DCP treated nuggets were harder and firmer than control while 3\% DTP treated nuggets were harder than control. Fibre addition resulted in less springier and less cohesive nuggets. Yellowness increased in DCP added nuggets while both redness and yellowness increased in DTP added nuggets. Fibre treated nuggets had less moisture and cholesterol content and higher protein, ash, crude fibre, emulsion stability and cooking yield. $\mathrm{pH}$ of DCP and DTP treated nuggets was lower than control. Drastic increase in total dietary fibre and insoluble dietary fibre content was observed in treated nuggets. Sensory scores of nuggets declined significantly while thiobarbituric acid reacting substance value (TBARS) and microbial counts increased significantly during refrigerated storage. It is concluded that incorporation of dietary fibre at $6 \%$ level resulted in healthier and fibre enriched nuggets with higher cooking yield and acceptability upto $15^{\text {th }}$ day of refrigerated storage.
\end{abstract}

Keywords: chicken nuggets, pomace, bran, cooking yield, dietary fibre, refrigerated storage

Recent epidemiological investigations have recognized the association of eating of meat products with prevalence of broad range of emerging diseases such as obesity, heart related diseases, cancer and various other disorders (Virtanen et al., 2019). It is well known that meat products are deficient in dietary fibre, so the fibre can be incorporated to make these products more healthful.

Codex Alimentarius Commission defined dietary fibre as the carbohydrate polymers with three or more than three monomers, which are not digested or absorbed in the human small intestine (Codex Alimentarius Commission, 2019). Addition of dietary fibre in the diet reduces the occurrence of cardiovascular disease, diabetes and certain types of cancer (The Lancet, 2019). Moreover, source of dietary fibres are common agricultural byproducts that are relatively low priced and their addition in meat may reduce overall production cost of meat products. The recommended intake of dietary fibre is $28-36 \mathrm{~g} /$ day for adults, of which 70-80\% should be insoluble fibre (Mehta et al., 2015).

The cereal brans have appreciable quantity of insoluble fibre, minerals, lipids, vitamins and pigments (Alan et $a l ., 2012$ ). Corn bran is an agro industrial by product. It provides high water holding capacity and has the potential to absorb faecal mutagens in human digestive track, protecting the body from the harmful effects of these

How to cite this article: Yadav, S., Pathera, A.K., Islam, R.U. and Malik, A. (2020). Effect of incorporation of corn bran, dried carrot pomace and dried tomato pomace on quality attributes of chicken nuggets. J. Anim Res., 10(2): 253-262. 
mutagens. Corn fibre does not exhibit its own taste and possesses antioxidant activity due to presence of bioactive compounds (Bauer et al., 2013).

Fruit and vegetable byproducts are a plentiful source of nutrients including dietary fibre and phytochemicals and can be utilized as new and cost effective sources of healthy and functional ingredients. Lycopene which is a proven cancer fighting phytochemical is the most abundant carotenoid present in tomato especially in its peel (OShea et al., 2012). Tomato pomace is also an abundant source of other bioactive compounds like tocopherols, polyphenols, terpenes and sterols (Kalogeropoulos et al., 2012) making it a worthy ingredient. Carrot pomace is produced after juice extraction and is rich in insoluble fibre rich fraction. It is chiefly composed of pectic polysaccharides, hemicellulose and cellulose. It carries approximately $80 \%$ of carrot carotenes (Baljeet et al., 2014).

Chicken nugget is a ready to eat convenience product requiring short preparation time. The product is popular among consumers due to high nutritional value and better organoleptic quality. Keeping above points in view, this study was carried to develop dietary fibre enriched chicken nuggets by incorporating corn bran (CB), dried carrot pomace (DCP) and dried tomato pomace (DTP) and study their effect on nutritional, physico-chemical and sensory quality of developed products.

\section{MATERIALS AND METHODS}

\section{Procurement and processing of dietary fibre sources}

Corn bran was procured from Vitarich agro food (India) Ltd., Kolkata. Carrot and tomato were procured from nearby market. Pomace of carrot and tomato were obtained after extraction of juice. Before extracting juice, tomatoes were blanched in hot water at $70^{\circ} \mathrm{C}$ for 2 minutes. Both types of pomace were separately dried. All the three fibre sources were ground, packaged in air tight container and stored under frozen conditions for further use.

\section{Preparation of chicken nuggets}

Deboned chicken meat was minced in an electrical mincer ( $4 \mathrm{~mm}$ plate). Control nuggets were prepared by adding sodium chloride (1.6 g), sodium tripolyphosphate
(STPP) (0.3 g), sodium nitrite (0.015 g), spice mix (1.9 g), condiments paste $(3 \mathrm{~g})$, refined wheat flour $(2 \mathrm{~g})$, water $(8$ $\mathrm{g})$, groundnut oil $(8 \mathrm{~g})$ and egg albumen $(10 \mathrm{~g})$ to minced meat (65.2 g).

Treated chicken nuggets were prepared by incorporating CB, DCP and DTP each at three different levels individually viz. 3, 6 and $9 \%$ by replacing lean meat. Other ingredients were used in similar concentration as in control. Minced meat along with additives and dietary fibre sources were mixed in a bowl chopper for 4 - 6 min to prepare a stable emulsion. Raw emulsion was packed in rectangular moulds and cooked in electric oven $\left(165^{\circ} \mathrm{C}\right.$ for $\left.40 \mathrm{~min}\right)$. Cooked emulsion was cooled to room temperature. Nuggets were prepared by cutting cooked emulsion to $2-3 \mathrm{~cm}^{3}$ size. They were packaged in polythene bags and stored at refrigerated temperature for further analysis.

\section{Analysis}

\section{Proximate composition and physicochemical properties}

Proximate composition (moisture, fat, protein, ash and crude fibre content) (AOAC, 1995), $\mathrm{pH}$ (Trout et al., 1992) and thiobarbituric acid reacting substances (TBARS) value (Witte et al., 1970) of chicken nuggets were analyzed by following the standard procedures. Emulsion stability of control and treated emulsions was analyzed using the procedure of Baliga and Madaiah (1970). Cooking yield was measured by recording the weight of the cooked nuggets and initial raw weight and expressed as a percentage.

\section{Dietary fibre content}

A combination of enzymatic and gravimetric method (AOAC, 1997) by utilizing TDF assay kit (Sigma-Aldrich Inc.) was used for estimating soluble dietary fibre (SDF), insoluble dietary fibre (IDF) and total dietary fibre (TDF) content.

\section{Cholesterol}

The total lipids from a sample were extracted as per the method of Angelo et al. (1987) with a little alteration. The total cholesterol content in the lipid extract was measured by following the spectrophotometric method 
of Zak (1957). Blank and standard solutions were run simultaneously along with samples and absorbance was recorded at $560 \mathrm{~nm}$.

\section{Texture profile analysis}

The analysis of texture profile of chicken nuggets was performed as per the procedure outlined by Bourne (1978) using TAHD Plus Texture Analyser (Stable Micro Systems, England). A compression platform of $70 \mathrm{~mm}$ diameter was used as a probe. Samples (20 mm cube size) were compressed to $50 \%$ of their original height. A time interval of $5 \mathrm{~s}$ was allowed between two compression cycles. Force time deformation curves were obtained with a $50 \mathrm{~kg}$ load cell applied at a cross head speed of $2 \mathrm{~mm} / \mathrm{s}$.

\section{Shear press value}

Force required to shear a nugget sample of $1 \mathrm{~cm}^{3}$ size was measured using warner bratzler shear probe of texture analyser and expressed in Newton $(\mathrm{N})$.

\section{Instrumental colour analysis}

CIE Lab, L* (lightness), a* (redness) and b* (yellowness) of cooked products were measured using a chroma meter (Konica Minolta Sensing, Inc., Japan) with $8 \mathrm{~mm}$ orifice for measurement. The equipment was standardized with a white standard plate before measurement.

\section{Sensory evaluation}

Chicken nuggets were evaluated for their sensory quality by a semi trained panel consisting of members from the faculty and research fellows of the department. Sensory characteristics i.e. colour and appearance, flavour, texture, tenderness, juiciness and overall acceptability (OAA) were analyzed using 8-point descriptive scale where score 8 and 1 indicated extremely desirable and extremely undesirable respectively.

\section{Microbiological analysis}

Standard plate count (SPC), psychrotrophic count (PC) and yeast and mold counts of chicken nuggets were estimated during refrigerated storage (APHA, 1984).

\section{Statistical analysis}

The data acquired were evaluated by analysis of variance (ANOVA). One way ANOVA for fresh products and two way ANOVA for refrigerated stored products was performed. To find out the significant differences in means, Duncan's multiple range test was used.

\section{RESULTS AND DISCUSSION}

\section{Sensory quality}

Colour and appearance scores of all CB and DCP treated nuggets and DCPN-1 nuggets incorporated with 3\% tomato pomace were similar to control (Table 1). Increase in colour scores in comparison to control was found in treatments DTPN-2 and DTPN-3 incorporated with $6 \%$ and $9 \%$ tomato pomace respectively. Increase in colour scores might be due to contribution of red colour by tomato peel present in DTP. O'Shea et al. (2012) reported that lycopene present in tomato peel is partially responsible for the red colour in tomatoes.

No significant difference was noticed in flavour, texture, juiciness, tenderness and overall acceptability scores of control and treatment CBN-1, DCPN-1 and DTPN-1 containing 3\% CB, 3\% DCP and 3\% DTP respectively. Flavour, texture, tenderness and overall acceptability scores of $\mathrm{CBN}-2$ containing $6 \% \mathrm{CB}$ were significantly lower in comparison to control. Flavour, juiciness and overall acceptability scores of treatment DCPN2 and flavour scores of treatment DTPN-2 were also significantly lower in comparison to control. However, overall acceptability scores of treatments CBN-2, DCPN2 and DTPN-2 were around 7.0 meaning very good acceptability. Except for colour scores, treatments CBN3, DCPN-3 and DTPN-3 had significantly lower scores for all other sensory attributes in comparison to control. Decrease in flavour scores at higher level of dietary fibre incorporation might be due to dilution of meaty flavour. Fibre rich ingredients may have their own characteristics flavour attributes like sourness, bitterness which affect the flavour of meat products. Goncalves et al. (2010) reported that anthocyanins and carotenoids present in carrot are responsible for its aroma and bitterness. Effect of fibre on physical strength and properties of meat emulsion might be responsible for its effect on texture and tenderness 
Table 1: Sensory scores of chicken nuggets incorporated with different levels of corn bran, dried carrot pomace and dried tomato pomace $(n=12$, mean $\pm S D)$

\begin{tabular}{lcccccc}
\hline Treatment & \multicolumn{1}{c}{ Colour \& appearance } & Flavour & Texture & Juiciness & Tenderness & OAA \\
\hline \multicolumn{7}{c}{ Chicken nuggets incorporated with corn bran } \\
\hline Control & $7.25 \pm 0.45^{\mathrm{a}}$ & $7.63 \pm 0.48^{\mathrm{a}}$ & $7.54 \pm 0.45^{\mathrm{a}}$ & $7.42 \pm 0.36^{\mathrm{a}}$ & $7.42 \pm 0.51^{\mathrm{a}}$ & $7.46 \pm 0.45^{\mathrm{a}}$ \\
CBN-1 & $7.38 \pm 0.48^{\mathrm{a}}$ & $7.42 \pm 0.51^{\mathrm{a}}$ & $7.42 \pm 0.42^{\mathrm{ab}}$ & $7.42 \pm 0.51^{\mathrm{a}}$ & $7.33 \pm 0.49^{\mathrm{a}}$ & $7.38 \pm 0.38^{\mathrm{ab}}$ \\
CBN-2 & $7.25 \pm 0.45^{\mathrm{a}}$ & $6.67 \pm 0.25^{\mathrm{b}}$ & $7.00 \pm 0.52^{\mathrm{b}}$ & $6.88 \pm 0.74^{\mathrm{a}}$ & $6.83 \pm 0.89^{\mathrm{b}}$ & $6.92 \pm 0.79^{\mathrm{b}}$ \\
CBN-3 & $7.17 \pm 0.39^{\mathrm{a}}$ & $5.92 \pm 0.67^{\mathrm{c}}$ & $6.25 \pm 0.69^{\mathrm{c}}$ & $6.00 \pm 0.80^{\mathrm{b}}$ & $6.08 \pm 0.42^{\mathrm{c}}$ & $5.96 \pm 0.72^{\mathrm{c}}$ \\
\hline \multicolumn{7}{c}{ Chicken nuggets incorporated with dried carrot pomace } \\
\hline Control & $7.42 \pm 0.51^{\mathrm{a}}$ & $7.58 \pm 0.51^{\mathrm{a}}$ & $7.50 \pm 0.52^{\mathrm{a}}$ & $7.67 \pm 0.49^{\mathrm{a}}$ & $7.58 \pm 0.51^{\mathrm{a}}$ & $7.63 \pm 0.48^{\mathrm{a}}$ \\
DCPN-1 & $7.46 \pm 0.50^{\mathrm{a}}$ & $7.42 \pm 0.51^{\mathrm{a}}$ & $7.42 \pm 0.51^{\mathrm{a}}$ & $7.67 \pm 0.54^{\mathrm{a}}$ & $7.33 \pm 0.49^{\mathrm{a}}$ & $7.42 \pm 0.51^{\mathrm{a}}$ \\
DCPN-2 & $7.17 \pm 0.39^{\mathrm{a}}$ & $6.92 \pm 0.67^{\mathrm{b}}$ & $7.17 \pm 0.25^{\mathrm{a}}$ & $7.21 \pm 0.58^{\mathrm{b}}$ & $7.17 \pm 0.58^{\mathrm{a}}$ & $7.04 \pm 0.26^{\mathrm{b}}$ \\
DCPN-3 & $7.13 \pm 0.38^{\mathrm{a}}$ & $6.08 \pm 0.67^{\mathrm{c}}$ & $6.17 \pm 0.83^{\mathrm{b}}$ & $6.08 \pm 0.42^{\mathrm{c}}$ & $6.04 \pm 0.40^{\mathrm{b}}$ & $6.08 \pm 0.47^{\mathrm{c}}$ \\
\hline Control & $7.17 \pm 0.39^{\mathrm{c}}$ & $7.75 \pm 0.40^{\mathrm{a}}$ & $7.50 \pm 0.90^{\mathrm{a}}$ & $7.42 \pm 0.47^{\mathrm{a}}$ & $7.42 \pm 0.51^{\mathrm{a}}$ & $7.50 \pm 0.48^{\mathrm{a}}$ \\
DTPN-1 & $7.33 \pm 0.49^{\mathrm{bc}}$ & $7.71 \pm 0.33^{\mathrm{a}}$ & $7.58 \pm 0.51^{\mathrm{a}}$ & $7.33 \pm 0.49^{\mathrm{a}}$ & $7.50 \pm 0.52^{\mathrm{a}}$ & $7.46 \pm 0.45^{\mathrm{a}}$ \\
DTPN-2 & $7.58 \pm 0.51^{\mathrm{ab}}$ & $7.00 \pm 0.74^{\mathrm{b}}$ & $7.25 \pm 0.45^{\mathrm{a}}$ & $7.00 \pm 0.48^{\mathrm{a}}$ & $7.17 \pm 0.58^{\mathrm{a}}$ & $7.04 \pm 0.33^{\mathrm{a}}$ \\
DTPN-3 & $7.75 \pm 0.45^{\mathrm{a}}$ & $6.08 \pm 0.90^{\mathrm{c}}$ & $6.33 \pm 0.78^{\mathrm{b}}$ & $6.17 \pm 0.83^{\mathrm{b}}$ & $6.38 \pm 0.83^{\mathrm{b}}$ & $6.17 \pm 0.94^{\mathrm{b}}$ \\
\hline
\end{tabular}

CBN-1, CBN-2, CBN-3= chicken nuggets incorporated with 3\%, $6 \%$ and $9 \%$ corn bran respectively; DCPN-1, DCPN-2, DCPN-3= chicken nuggets incorporated with $3 \%, 6 \%$ and $9 \%$ dried carrot pomace respectively; DTPN-1, DTPN-2, DTPN-3= chicken nuggets incorporated with $3 \%, 6 \%$ and $9 \%$ dried tomato pomace respectively; Means with different superscripts within a column for a particular fibre treatment differ significantly $(\mathrm{p} \leq 0.05)$.

of meat products. Fibre binds water which might have resulted in decreased juiciness in fibre treated nuggets. Incorporation of corn bran and dried apple pomace at $6 \%$ level individually resulted in a decrease in sensory scores of chevon rolls (Parkash et al., 2016). Mehta et al. (2013) also reported a decrease in sensory scores of chicken rolls and patties with increasing levels of rice bran and psyllium husk.

\section{Instrumental texture and colour properties}

Hardness scores of CB, DCP and DTP treated nuggets showed a variable trend (Table 2). Hardness declined significantly in $\mathrm{CBN}-1$ nuggets, then it increased and treatment $\mathrm{CBN}-2$ had significantly highest hardness value. $\mathrm{CBN}-3$ treatment had hardness scores in between control and $\mathrm{CBN}-2$. Hardness increased significantly in DCPN-2 and DCPN-3 nuggets in comparison to control. DCPN-3 nuggets had significantly lower hardness scores in comparison to DCPN-2 nuggets. In DTPN nuggets, treatment DTPN-1 had significantly higher hardness and treatment DTPN-2 had significantly lower hardness in comparison to control and DTPN-1 treatment. Treatment
DTPN-3 had hardness scores in between treatment DTPN2 and control. Results indicate that peak of hardness was observed in treatments $\mathrm{CBN}-2$ and $\mathrm{DCPN}-2$ in $\mathrm{CB}$ and DCP treated nuggets and in treatment DTPN-1 in DTP treated nuggets respectively. Springiness and cohesiveness decreased significantly with progressive increase in fibre level in treated nuggets. Chemical composition and type of dietary fibre influence the textural properties of meat products. Fibres also influence textural properties due to their interaction with meat matrix during processing and development of meat products. Grossi et al. (2011) reported that addition of $2 \%$ carrot dietary fibre in comminuted meat emulsion induces a high order of network organization leading to a higher compressive strength. Hardness increased significantly in tomato fibre added cooked chicken products (Cava et al., 2012). Kumar et al. (2019) also reported a significant increase in hardness of functional pork patties incorporated with dried kinnow pomace powder. Sharoba et al. (2013) reported that cohesiveness quantifies the internal resistance of food structure. Decreased cohesiveness might be due to effect of fibre in facilitating the fragmentation of product resulting in ease in mastication and decrease in cohesiveness. 
Table 2: Instrumental texture and colour properties of chicken nuggets incorporated with different levels of corn bran, dried carrot pomace and dried tomato pomace $(\mathrm{n}=6$, mean $\pm \mathrm{SD})$

\begin{tabular}{|c|c|c|c|c|c|c|c|c|c|}
\hline \multirow[b]{2}{*}{ Treatment } & \multicolumn{6}{|c|}{ Texture properties } & \multicolumn{3}{|c|}{ Colour properties } \\
\hline & Hardness & Springiness & Cohesiveness & Gumminess & Chewiness & $\begin{array}{l}\text { Shear force } \\
\text { value }\end{array}$ & $\mathbf{L}^{*}$ & $a^{*}$ & $\mathbf{b}^{*}$ \\
\hline \multicolumn{10}{|c|}{ Chicken nuggets incorporated with corn bran } \\
\hline Control & $52.28 \pm 2.85^{\mathrm{b}}$ & $0.89 \pm 0.02^{\mathrm{a}}$ & $0.66 \pm 0.02^{\mathrm{a}}$ & $34.50 \pm 2.14^{\mathrm{a}}$ & $30.56 \pm 1.76^{\mathrm{a}}$ & $6.01 \pm 0.45^{\mathrm{c}}$ & $52.03 \pm 2.49$ & $6.72 \pm 0.65$ & $17.04 \pm 1.37$ \\
\hline $\mathrm{CBN}-1$ & $46.16 \pm 3.62^{\mathrm{c}}$ & $0.84 \pm 0.03^{b}$ & $0.48 \pm 0.02^{\mathrm{b}}$ & $22.16 \pm 2.36^{\mathrm{c}}$ & $18.56 \pm 1.87^{\mathrm{c}}$ & $6.84 \pm 0.44^{\mathrm{b}}$ & $52.59 \pm 3.18$ & $6.33 \pm 0.31$ & $17.70 \pm 1.12$ \\
\hline $\mathrm{CBN}-2$ & $56.60 \pm 2.16^{\mathrm{a}}$ & $0.82 \pm 0.03^{b}$ & $0.46 \pm 0.02^{\mathrm{b}}$ & $26.15 \pm 1.45^{\mathrm{b}}$ & $21.28 \pm 1.12^{\mathrm{b}}$ & $11.15 \pm 0.70^{\mathrm{a}}$ & $52.96 \pm 2.61$ & $6.37 \pm 0.67$ & $17.39 \pm 1.07$ \\
\hline $\mathrm{CBN}-3$ & $54.16 \pm 2.84^{\mathrm{ab}}$ & $0.80 \pm 0.01^{\mathrm{c}}$ & $0.36 \pm 0.03^{\mathrm{c}}$ & $18.99 \pm 1.39^{\mathrm{d}}$ & $14.98 \pm 1.17^{\mathrm{d}}$ & $10.72 \pm 0.50^{\mathrm{a}}$ & $53.11 \pm 3.05$ & $6.20 \pm 0.29$ & $18.10 \pm 0.59$ \\
\hline \multicolumn{10}{|c|}{ Chicken nuggets incorporated with dried carrot pomace } \\
\hline Control & $50.27 \pm 4.07^{\mathrm{c}}$ & $0.89 \pm 0.02^{\mathrm{a}}$ & $0.68 \pm 0.02^{\mathrm{a}}$ & $34.31 \pm 3.47^{\mathrm{b}}$ & $30.58 \pm 3.66^{\mathrm{b}}$ & $6.24 \pm 0.94^{\mathrm{b}}$ & $53.05 \pm 3.35^{\mathrm{a}}$ & $6.78 \pm 0.72$ & $17.35 \pm 0.98^{b}$ \\
\hline DCPN-1 & $54.54 \pm 4.18^{\mathrm{c}}$ & $0.85 \pm 0.02^{\mathrm{b}}$ & $0.59 \pm 0.03^{\mathrm{b}}$ & $32.32 \pm 3.75^{\mathrm{bc}}$ & $27.28 \pm 3.19^{b}$ & $7.72 \pm 0.86^{\mathrm{a}}$ & $52.86 \pm 4.16^{\mathrm{a}}$ & $7.12 \pm 0.98$ & $18.34 \pm 1.81^{b}$ \\
\hline DCPN-2 & $81.34 \pm 2.77^{\mathrm{a}}$ & $0.79 \pm 0.02^{\mathrm{c}}$ & $0.55 \pm 0.03^{\mathrm{c}}$ & $45.00 \pm 3.10^{\mathrm{a}}$ & $35.36 \pm 2.71^{\mathrm{a}}$ & $7.78 \pm 0.67^{\mathrm{a}}$ & $52.80 \pm 4.09^{\mathrm{a}}$ & $7.12 \pm 0.88$ & $18.40 \pm 1.58^{b}$ \\
\hline DCPN-3 & $65.69 \pm 4.94^{\mathrm{b}}$ & $0.77 \pm 0.02^{\mathrm{c}}$ & $0.44 \pm 0.03^{\mathrm{d}}$ & $28.65 \pm 3.66^{\mathrm{c}}$ & $21.85 \pm 2.46^{\mathrm{c}}$ & $8.57 \pm 0.82^{\mathrm{a}}$ & $51.29 \pm 3.11^{\mathrm{a}}$ & $7.44 \pm 0.51$ & $20.80 \pm 1.71^{\mathrm{a}}$ \\
\hline \multicolumn{10}{|c|}{ Chicken nuggets incorporated with dried tomato pomace } \\
\hline Control & $50.41 \pm 3.04^{b}$ & $0.87 \pm 0.03^{\text {a }}$ & $0.68 \pm 0.03^{\mathrm{a}}$ & $34.29 \pm 2.80^{\mathrm{a}}$ & $29.80 \pm 2.30^{\mathrm{a}}$ & $6.34 \pm 0.74$ & $52.74 \pm 2.05^{\mathrm{a}}$ & $6.53 \pm 0.65^{b}$ & $17.35 \pm 1.24^{\mathrm{d}}$ \\
\hline DTPN-1 & $56.95 \pm 4.52^{\mathrm{a}}$ & $0.82 \pm 0.01^{b}$ & $0.60 \pm 0.02^{b}$ & $33.82 \pm 3.36^{\mathrm{a}}$ & $27.94 \pm 2.74^{\mathrm{a}}$ & $7.03 \pm 0.58$ & $52.50 \pm 3.00^{\mathrm{a}}$ & $7.19 \pm 0.59^{\mathrm{a}}$ & $19.72 \pm 0.71^{\mathrm{c}}$ \\
\hline DTPN-2 & $44.35 \pm 4.46^{\mathrm{c}}$ & $0.81 \pm 0.03^{b}$ & $0.39 \pm 0.02^{\mathrm{c}}$ & $16.65 \pm 1.37^{\mathrm{b}}$ & $13.55 \pm 1.20^{\mathrm{b}}$ & $6.39 \pm 0.73$ & $51.61 \pm 1.89^{\mathrm{a}}$ & $7.76 \pm 0.77^{\mathrm{a}}$ & $21.53 \pm 1.90^{\mathrm{b}}$ \\
\hline DTPN-3 & $47.32 \pm 2.37 \mathrm{bc}$ & $0.76 \pm 0.03^{\mathrm{c}}$ & $0.35 \pm 0.02^{\mathrm{d}}$ & $15.92 \pm 0.83^{\mathrm{b}}$ & $12.21 \pm 0.70^{\mathrm{b}}$ & $6.79 \pm 0.99$ & $51.48 \pm 2.90^{\mathrm{a}}$ & $7.63 \pm 0.26^{\mathrm{a}}$ & $24.90 \pm 1.62^{\mathrm{a}}$ \\
\hline
\end{tabular}

CBN-1, CBN-2, CBN-3= chicken nuggets incorporated with 3\%, $6 \%$ and $9 \%$ corn bran respectively; DCPN-1, DCPN-2, DCPN-3= chicken nuggets incorporated with $3 \%, 6 \%$ and $9 \%$ dried carrot pomace respectively; DTPN-1, DTPN-2, DTPN-3= chicken nuggets incorporated with 3\%,6\% and $9 \%$ dried tomato pomace respectively; Means with different superscripts within a column for a particular fibre treatment differ significantly $(\mathrm{p} \leq 0.05)$.

Gumminess and chewiness scores were significantly lower in all $\mathrm{CB}$ treated nuggets. Scores of gumminess and chewiness depend on the scores of hardness, cohesiveness and springiness. Lower springiness and cohesiveness scores in $\mathrm{CB}$ treatments contributed to their lower gumminess and chewiness values. In DCP treated nuggets, gumminess and chewiness scores of DCPN2 were significantly highest and DCPN-3 significantly lowest among all treatments. Highest hardness scores of DCPN-2 contributed to its highest gumminess and chewiness scores. Lowest springiness and cohesiveness scores and lower hardness in comparison to control and DCPN-2 treatments contributed to lowest gumminess and chewiness scores of DCPN-3 nuggets. DTPN-2 and DTPN-3 had significantly lower gumminess and chewiness than control. Firmness scores of all $\mathrm{CB}$ and DCP treated nuggets were significantly higher than control while firmness scores of DTP treated nuggets were similar to control.

No significant difference was noticed in lightness, redness and yellowness values of control and CB treated chicken nuggets. Lightness and redness values of DCP treated nuggets were statistically similar to control. Yellowness scores of nuggets increased with increase in DCP and treatment DCPN-3 had significantly higher yellowness scores in comparison to control. A significant increase in redness and yellowness was noticed in DTP nuggets. Dietary fibres influence colour of meat products by virtue of their inherent colour and characteristics. Increase in yellowness might be due to presence of anthocyanins and carotenoids (Goncalves et al., 2010). Incorporation of TF contributed to proportionate increase in lightness, redness and yellowness (Cava et al., 2012).

\section{Proximate composition and physico-chemical properties}

Treatments CBN-2, DCPN-2 and DTPN-2 containing $6 \% \mathrm{CB}, 6 \% \mathrm{DCP}$ and $6 \%$ DTP were selected for further study on the basis of sensory evaluation. There was a 
Table 3: Proximate composition, physico-chemical properties, dietary fibre and cholesterol content of chicken nuggets incorporated with different levels of corn bran, dried carrot pomace and dried tomato pomace $(n=6$, mean $\pm S D$ )

\begin{tabular}{lllll}
\hline Treatment & Control & CBN-2 & DCPN-2 & DTPN-2 \\
\hline Moisture (\%) & $62.38 \pm 0.76^{\mathrm{a}}$ & $60.08 \pm 0.86^{\mathrm{b}}$ & $60.71 \pm 1.06^{\mathrm{b}}$ & $59.81 \pm 0.81^{\mathrm{b}}$ \\
Protein (\%) & $17.74 \pm 0.73^{\mathrm{a}}$ & $16.18 \pm 0.50^{\mathrm{bc}}$ & $15.76 \pm 0.63^{\mathrm{c}}$ & $16.71 \pm 0.65^{\mathrm{b}}$ \\
Fat (\%) & $13.41 \pm 0.68^{\mathrm{a}}$ & $13.34 \pm 0.50^{\mathrm{a}}$ & $12.88 \pm 0.58^{\mathrm{a}}$ & $12.83 \pm 0.56^{\mathrm{a}}$ \\
Ash (\%) & $2.82 \pm 0.18^{\mathrm{c}}$ & $2.93 \pm 0.15^{\mathrm{bc}}$ & $3.11 \pm 0.13^{\mathrm{ab}}$ & $3.26 \pm 0.18^{\mathrm{a}}$ \\
Crude Fibre (\%) & $0.27 \pm 0.13^{\mathrm{c}}$ & $1.35 \pm 0.18^{\mathrm{b}}$ & $1.24 \pm 0.20^{\mathrm{b}}$ & $2.08 \pm 0.22^{\mathrm{a}}$ \\
Cooking yield (\%) & $90.40 \pm 0.99^{\mathrm{b}}$ & $92.43 \pm 0.84^{\mathrm{a}}$ & $92.32 \pm 0.72^{\mathrm{a}}$ & $91.85 \pm 0.84^{\mathrm{a}}$ \\
ES (\%) & $93.84 \pm 1.15^{\mathrm{b}}$ & $95.55 \pm 0.79^{\mathrm{a}}$ & $96.30 \pm 0.93^{\mathrm{a}}$ & $95.64 \pm 1.17^{\mathrm{a}}$ \\
pH & $6.54 \pm 0.05^{\mathrm{a}}$ & $6.50 \pm 0.06^{\mathrm{a}}$ & $6.07 \pm 0.05^{\mathrm{b}}$ & $5.98 \pm 0.05^{\mathrm{c}}$ \\
TDF (n=3) & $0.41 \pm 0.11^{\mathrm{c}}$ & $3.15 \pm 0.30^{\mathrm{b}}$ & $4.00 \pm 0.34^{\mathrm{a}}$ & $3.07 \pm 0.32^{\mathrm{b}}$ \\
IDF (n=3) & $0.24 \pm 0.07^{\mathrm{c}}$ & $2.91 \pm 0.26^{\mathrm{b}}$ & $3.49 \pm 0.28^{\mathrm{a}}$ & $2.72 \pm 0.28^{\mathrm{b}}$ \\
SDF (n=3) & $0.16 \pm 0.04^{\mathrm{c}}$ & $0.24 \pm 0.05^{\mathrm{c}}$ & $0.51 \pm 0.07^{\mathrm{a}}$ & $0.35 \pm 0.06^{\mathrm{b}}$ \\
Cholesterol & $64.89 \pm 3.14^{\mathrm{a}}$ & $57.53 \pm 3.32^{\mathrm{b}}$ & $57.82 \pm 1.95^{\mathrm{b}}$ & $58.12 \pm 2.17^{\mathrm{b}}$ \\
\hline
\end{tabular}

Moisture, protein, fat, ash and crude fibre content of $\mathrm{CB}$ was $11.62,10.81,6.08,2.14$ and 16.64 respectively. Corresponding values for DCP and DTP were 5.09, 6.47, 2.26, 5.98 and 12.93 and 7.54, 15.15, 4.38, 4.08 and 27.33 respectively; CBN-2, DCPN-2 and DTPN-2: Chicken nuggets incorporated with $6 \%$ corn bran, $6 \%$ dried carrot pomace and $6 \%$ dried tomato pomace respectively; Means with different superscripts within a row differ significantly $(\mathrm{p} \leq 0.05)$.

significant decrease in moisture content in fibre enriched nuggets in comparison to control (Table 3). Substitution of high moisture containing meat with very low moisture containing dietary fibre ingredients resulted in lower moisture content in treated nuggets. Protein content also decreased significantly with fibre incorporation in nuggets. Significantly lowest protein content was noticed in DCP incorporated nuggets which was due to lower protein content in DCP in comparison to DTP and corn bran. Moisture and protein content also decreased in corn bran and dried apple pomace incorporated chicken sausages (Yadav et al., 2016). No significant difference was noticed in fat content. Ash content of treated nuggets also increased and significant increase in comparison to control was noticed in DCP and DTP incorporated nuggets. A significant increase in crude fibre content was noticed in treated nuggets. Treatment DTPN-2 had significantly highest crude fibre content which was due to higher crude fibre content in DTP in comparison to DCP and CB. Emulsion stability of chicken meat increased significantly after fibre incorporation resulting in a significant increase in cooking yield of treated nuggets. Increased emulsion stability and yield were due to positive effect of fibre on water and fat retention. Addition of tomato fibre at the level $1 \%$ to $3 \%$ significantly reduced cooking loss of chicken products (Cava et al., 2012). Emulsion stability and cooking yield increased significantly in functional pork patties incorporated with dried kinnow pomace powder (Kumar et al., 2019). pH of DCP and DTP incorporated nuggets was significantly lower than control. This decrease can be attributed to acidic $\mathrm{pH}$ of carrot and tomato pomace. $\mathrm{pH}$ of DAP treated chevon rolls was significantly lower than control (Parkash et al., 2016).

\section{Dietary fibre and cholesterol content}

Significant and drastic increase in TDF and IDF content of treated nuggets was observed. This was obvious due to higher amount of fibre content in dietary fibre ingredients. SDF content of treatments DCPN-2 and DTPN-2 was also significantly higher than control. Treatment DCPN-2 had significantly highest TDF, SDF and IDF which was due to significantly highest TDF, SDF and IDF content in DCP. Comparatively, the increase in TDF and IDF content was more appreciable than increase in SDF. This was also due to nature of dietary fibre present in materials used. Tomato fibre contained more amount of insoluble fraction in comparison to soluble fraction (Ratio 10:1) and its fibre type resembled more with cereals (Garcia et al., 2010). Cholesterol content of fibre added samples was significantly lower than control. 


\section{Sensory quality of treated nuggets during refrigerated} storage

Colour and appearance scores of treatment DTPN-2 were significantly higher than all other treatments during entire storage period (Table 4). Colour scores decreased significantly in all the treatments during storage. Decrease in colour scores might be due to oxidation of pigments during storage.

Flavour scores of control nuggets were significantly higher than fibre enriched nuggets on 0 day. Flavour scores of all the nuggets decreased significantly during storage. At the end of storage period of 15 days, flavour scores of DCPN-2 and DTPN-2 nuggets were statistically similar to control. The results indicate that DCP and DTP incorporation resulted in a positive effect on flavour scores of nuggets during refrigerated storage. Flavour scores of both control and fibre enriched nuggets were above 6.0 at the end of refrigerated storage indicating more than moderate acceptability.

Texture and tenderness scores of control and treatments DCPN-2 and DTPN-2 were comparable on 0 day as well as during storage. Texture and tenderness scores of treatment

Table 4: Sensory scores of corn bran, dried carrot pomace and dried tomato pomace incorporated chicken nuggets stored at $4 \pm 1{ }^{\circ} \mathrm{C}$ $(\mathrm{n}=12$, Mean $\pm \mathrm{SD})$

\begin{tabular}{|c|c|c|c|c|}
\hline Treatment & 0 Day & 5 day & 10 day & 15 day \\
\hline \multicolumn{5}{|c|}{ Colour } \\
\hline Control & $7.25 \pm 0.40^{\mathrm{bA}}$ & $7.08 \pm 0.36^{\mathrm{bAB}}$ & $6.83 \pm 0.33 \mathrm{bBC}$ & $6.67 \pm 0.54 \mathrm{bC}$ \\
\hline $\mathrm{CBN}-2$ & $7.04 \pm 0.26^{\mathrm{bA}}$ & $7.00 \pm 0.30^{\mathrm{bA}}$ & $6.75 \pm 0.40^{\mathrm{bAB}}$ & $6.50 \pm 0.52^{\mathrm{bB}}$ \\
\hline DCPN-2 & $7.08 \pm 0.36^{\mathrm{bA}}$ & $7.00 \pm 0.21^{\mathrm{bAB}}$ & $6.67 \pm 0.49 \mathrm{bBC}$ & $6.54 \pm 0.50^{\mathrm{bC}}$ \\
\hline DTPN-2 & $7.67 \pm 0.44^{\mathrm{aA}}$ & $7.63 \pm 0.48^{\mathrm{aA}}$ & $7.42 \pm 0.51^{\mathrm{aAB}}$ & $7.17 \pm 0.39 \mathrm{aB}$ \\
\hline \multicolumn{5}{|c|}{ Flavour } \\
\hline Control & $7.67 \pm 0.49^{\mathrm{aA}}$ & $7.33 \pm 0.44^{\mathrm{aAB}}$ & $7.08 \pm 0.47 \mathrm{aBC}$ & $6.75 \pm 0.45^{\mathrm{aC}}$ \\
\hline CBN-2 & $6.79 \pm 0.40 \mathrm{bA}$ & $6.75 \pm 0.58^{\mathrm{bA}}$ & $6.42 \pm 0.47^{\mathrm{bAB}}$ & $6.17 \pm 0.54^{\mathrm{bB}}$ \\
\hline DCPN-2 & $6.96 \pm 0.50^{\mathrm{bA}}$ & $6.83 \pm 0.39 \mathrm{bA}$ & $6.67 \pm 0.54 \mathrm{bAB}$ & $6.33 \pm 0.49 \mathrm{abB}$ \\
\hline DTPN-2 & $7.04 \pm 0.40^{\mathrm{bA}}$ & $6.83 \pm 0.44^{\mathrm{bAB}}$ & $6.63 \pm 0.53^{\mathrm{bBC}}$ & $6.42 \pm 0.47^{\mathrm{abC}}$ \\
\hline \multicolumn{5}{|c|}{ Texture } \\
\hline Control & $7.63 \pm 0.48 \mathrm{aA}$ & $7.50 \pm 0.48^{\mathrm{aA}}$ & $7.25 \pm 0.45^{\mathrm{aA}}$ & $6.83 \pm 0.54^{\mathrm{aB}}$ \\
\hline $\mathrm{CBN}-2$ & $6.96 \pm 0.40^{\mathrm{bA}}$ & $6.92 \pm 0.36^{\mathrm{bA}}$ & $6.67 \pm 0.39 \mathrm{bA}$ & $6.29 \pm 0.45 \mathrm{bB}$ \\
\hline DCPN-2 & $7.29 \pm 0.45^{\mathrm{abA}}$ & $7.17 \pm 0.39 \mathrm{abAB}$ & $6.92 \pm 0.29 \mathrm{abBC}$ & $6.67 \pm 0.44^{\mathrm{abC}}$ \\
\hline DTPN-2 & $7.25 \pm 0.45^{\mathrm{abA}}$ & $7.21 \pm 0.45^{\mathrm{abA}}$ & $6.96 \pm 0.40^{\mathrm{abA}}$ & $6.58 \pm 0.47^{\mathrm{abB}}$ \\
\hline \multicolumn{5}{|c|}{ Juiciness } \\
\hline Control & $7.58 \pm 0.47^{\mathrm{aA}}$ & $7.33 \pm 0.49^{\mathrm{aA}}$ & $7.17 \pm 0.54^{\mathrm{aAB}}$ & $6.88 \pm 0.48^{a B}$ \\
\hline $\mathrm{CBN}-2$ & $6.96 \pm 0.33 \mathrm{bA}$ & $6.83 \pm 0.39 \mathrm{bA}$ & $6.63 \pm 0.53 \mathrm{bAB}$ & $6.38 \pm 0.48^{\mathrm{bB}}$ \\
\hline DCPN-2 & $7.17 \pm 0.54^{\mathrm{bA}}$ & $7.08 \pm 0.47^{\mathrm{abA}}$ & $6.79 \pm 0.62^{\mathrm{abAB}}$ & $6.58 \pm 0.47^{\mathrm{abB}}$ \\
\hline DTPN-2 & $7.21 \pm 0.40^{\mathrm{bA}}$ & $7.04 \pm 0.50^{\mathrm{ab} \mathrm{AB}}$ & $6.83 \pm 0.39^{\mathrm{abAB}}$ & $6.67 \pm 0.44^{\mathrm{abB}}$ \\
\hline \multicolumn{5}{|c|}{ Tenderness } \\
\hline Control & $7.54 \pm 0.50$ aA & $7.42 \pm 0.51 \mathrm{aAB}$ & $7.13 \pm 0.31 \mathrm{aBC}$ & $6.83 \pm 0.39^{\mathrm{aC}}$ \\
\hline $\mathrm{CBN}-2$ & $6.92 \pm 0.47 \mathrm{bA}$ & $6.75 \pm 0.58^{\mathrm{bAB}}$ & $6.58 \pm 0.51^{\mathrm{bAB}}$ & $6.33 \pm 0.49 \mathrm{bB}$ \\
\hline DCPN-2 & $7.21 \pm 0.45^{\mathrm{abA}}$ & $7.08 \pm 0.51^{\mathrm{abA}}$ & $6.83 \pm 0.33^{\mathrm{abAB}}$ & $6.58 \pm 0.47^{\mathrm{abB}}$ \\
\hline DTPN-2 & $7.17 \pm 0.33^{\mathrm{abA}}$ & $7.08 \pm 0.36^{\mathrm{abA}}$ & $6.83 \pm 0.62^{\mathrm{abAB}}$ & $6.50 \pm 0.52^{\mathrm{abB}}$ \\
\hline \multicolumn{5}{|c|}{ OAA } \\
\hline Control & $7.63 \pm 0.48^{\mathrm{aA}}$ & $7.38 \pm 0.48^{\mathrm{aAB}}$ & $7.13 \pm 0.31^{\mathrm{aB}}$ & $6.75 \pm 0.50^{\mathrm{aC}}$ \\
\hline $\mathrm{CBN}-2$ & $6.96 \pm 0.40^{\mathrm{bA}}$ & $6.75 \pm 0.34^{\mathrm{bA}}$ & $6.58 \pm 0.47^{\mathrm{bA}}$ & $6.21 \pm 0.54^{\mathrm{bB}}$ \\
\hline DCPN-2 & $7.17 \pm 0.49^{\mathrm{bA}}$ & $7.04 \pm 0.40^{\mathrm{bA}}$ & $6.83 \pm 0.54^{\mathrm{abA}}$ & $6.42 \pm 0.56^{\mathrm{abB}}$ \\
\hline DTPN-2 & $7.21 \pm 0.45^{\mathrm{bA}}$ & $7.00 \pm 0.37^{\mathrm{bAB}}$ & $6.79 \pm 0.40^{\mathrm{abBC}}$ & $6.50 \pm 0.48^{\mathrm{abC}}$ \\
\hline
\end{tabular}

CBN-2, DCPN-2 and DTPN-2: Chicken nuggets incorporated with $6 \%$ corn bran, $6 \%$ dried carrot pomace and $6 \%$ dried tomato pomace respectively; Means with different small superscripts within a column and capital superscripts within a row for a particular parameter differ significantly $(\mathrm{p} \leq 0.05)$. 
CBN-2 were significantly lower than control on all days of storage. The scores for texture and tenderness decreased significantly in both control and treated nuggets during storage but the scores were well within the acceptability limits at the end of storage. Juiciness scores of treated nuggets were significantly lower than control nuggets on 0 day. Juiciness scores declined significantly in all the treatments during storage. From $5^{\text {th }}$ day onwards, juiciness scores of DCPN-2 and DTPN-2 were comparable with control till the end of storage period. Results indicate that carrot pomace and tomato pomace were able to retain meat juices in a better way. Overall acceptability scores of fresh control nuggets were significantly higher than fresh treated nuggets. The OAA scores of control and treated nuggets declined significantly during storage. However, OAA scores of DCPN-2 and DTPN-2 treatments were comparable with control on $15^{\text {th }}$ day of storage.

\section{TBARS value and microbiological quality}

No significant difference was noticed in TBARS value of control and treated nuggets on 0 day. Significant increase in TBARS value of control and treated nuggets was noticed with increase in storage period. However, the rate of increase was less in DCP and DTP treated nuggets resulting in significantly lower TBARS value of DCPN-2 and DTPN-2 treatments in comparison to control on $20^{\text {th }}$ day of storage. Bioactive compounds in pomace might have contributed to antioxidant effect.

No significant difference was noticed in any of the microbial counts between control and treated nuggets on 0 day as well as during storage (Table 5). Microbial counts increased significantly during storage in both control and treated nuggets. However, the counts were within the safety limits up to $15^{\text {th }}$ day of refrigerated storage. On $20^{\text {th }}$

Table 5: TBARS value and microbiological quality of corn bran, dried carrot pomace and dried tomato pomace incorporated chicken nuggets stored at $4 \pm 1^{\circ} \mathrm{C}(\mathrm{n}=6$, Mean \pm SD)

\begin{tabular}{|c|c|c|c|c|c|}
\hline & O day & $5^{\text {th }}$ day & $10^{\text {th }}$ day & $15^{\text {th }}$ day & $20^{\text {th }}$ day \\
\hline \multicolumn{6}{|c|}{ TBARS value (mg malonaldehyde/kg) } \\
\hline$\overline{\text { Control }}$ & $0.86 \pm 0.27 \mathrm{aC}$ & $1.05 \pm 0.21^{\mathrm{aC}}$ & $1.64 \pm 0.19^{\mathrm{aB}}$ & $1.86 \pm 0.26^{\mathrm{aB}}$ & $2.39 \pm 0.23^{\mathrm{aA}}$ \\
\hline $\mathrm{CBN}-2$ & $0.84 \pm 0.14 \mathrm{aD}$ & $1.08 \pm 0.25 \mathrm{aC}$ & $1.56 \pm 0.12^{\mathrm{aB}}$ & $1.68 \pm 0.18 \mathrm{aB}$ & $2.32 \pm 0.13^{\mathrm{aA}}$ \\
\hline DCPN-2 & $0.78 \pm 0.11^{\mathrm{aE}}$ & $0.97 \pm 0.15^{\mathrm{aD}}$ & $1.42 \pm 0.16^{\mathrm{aC}}$ & $1.64 \pm 0.24 \mathrm{aB}$ & $2.10 \pm 0.09 \mathrm{bA}$ \\
\hline DTPN-2 & $0.80 \pm 0.24^{\mathrm{aC}}$ & $0.95 \pm 0.14^{\mathrm{aC}}$ & $1.40 \pm 0.27^{\mathrm{aB}}$ & $1.55 \pm 0.25^{\mathrm{aB}}$ & $2.05 \pm 0.19 \mathrm{bA}$ \\
\hline \multicolumn{6}{|c|}{ Standard plate count (log cfu/g) } \\
\hline$\overline{\text { Control }}$ & $2.62 \pm 0.31^{\mathrm{E}}$ & $3.28 \pm 0.36^{\mathrm{D}}$ & $4.24 \pm 0.28^{\mathrm{C}}$ & $5.28 \pm 0.41^{\mathrm{B}}$ & $6.17 \pm 0.37^{\mathrm{A}}$ \\
\hline $\mathrm{CBN}-2$ & $2.59 \pm 0.38^{\mathrm{E}}$ & $3.19 \pm 0.23^{\mathrm{D}}$ & $4.11 \pm 0.42^{\mathrm{C}}$ & $5.22 \pm 0.42^{\mathrm{B}}$ & $6.33 \pm 0.40^{\mathrm{A}}$ \\
\hline DCPN-2 & $2.74 \pm 0.43^{\mathrm{E}}$ & $3.31 \pm 0.30^{\mathrm{D}}$ & $4.31 \pm 0.43^{\mathrm{C}}$ & $5.06 \pm 0.28^{\mathrm{B}}$ & $6.14 \pm 0.37^{\mathrm{A}}$ \\
\hline DTPN-2 & $2.47 \pm 0.32^{\mathrm{E}}$ & $3.18 \pm 0.28^{\mathrm{D}}$ & $4.14 \pm 0.32^{\mathrm{C}}$ & $5.03 \pm 0.23^{\text {B }}$ & $6.19 \pm 0.28^{\mathrm{A}}$ \\
\hline \multicolumn{6}{|c|}{ Psychrotrophic count (log cfu/g) } \\
\hline Control & $1.48 \pm 0.30^{\mathrm{D}}$ & $2.01 \pm 0.38^{\mathrm{C}}$ & $2.59 \pm 0.29^{\mathrm{B}}$ & $2.99 \pm 0.24^{\mathrm{B}}$ & $3.64 \pm 0.42^{\mathrm{A}}$ \\
\hline $\mathrm{CBN}-2$ & $1.49 \pm 0.34^{\mathrm{C}}$ & $1.90 \pm 0.39^{\mathrm{C}}$ & $2.52 \pm 0.34^{\mathrm{B}}$ & $3.19 \pm 0.39^{\mathrm{A}}$ & $3.48 \pm 0.38^{\mathrm{A}}$ \\
\hline DCPN-2 & $1.31 \pm 0.26^{\mathrm{E}}$ & $1.76 \pm 0.41^{\mathrm{D}}$ & $2.39 \pm 0.29^{\mathrm{C}}$ & $2.96 \pm 0.41^{\mathrm{B}}$ & $3.55 \pm 0.36^{\mathrm{A}}$ \\
\hline DTPN-2 & $1.42 \pm 0.38^{\mathrm{E}}$ & $1.89 \pm 0.34^{\mathrm{D}}$ & $2.41 \pm 0.24^{\mathrm{C}}$ & $3.07 \pm 0.45^{\mathrm{B}}$ & $3.62 \pm 0.40^{\mathrm{A}}$ \\
\hline \multicolumn{6}{|c|}{ Yeast and mold count (log $\mathrm{cfu} / \mathrm{g})$} \\
\hline Control & $0.97 \pm 0.25^{\mathrm{E}}$ & $1.43 \pm 0.46^{\mathrm{D}}$ & $1.97 \pm 0.42^{\mathrm{C}}$ & $2.59 \pm 0.36^{\mathrm{B}}$ & $3.22 \pm 0.32^{\mathrm{A}}$ \\
\hline $\mathrm{CBN}-2$ & $0.98 \pm 0.25^{\mathrm{D}}$ & $1.54 \pm 0.39^{\mathrm{C}}$ & $2.05 \pm 0.37^{\text {B }}$ & $2.45 \pm 0.41^{\mathrm{B}}$ & $3.10 \pm 0.30^{\mathrm{A}}$ \\
\hline DCPN-2 & $1.26 \pm 0.35^{\mathrm{C}}$ & $1.62 \pm 0.29^{\mathrm{C}}$ & $2.18 \pm 0.40^{\mathrm{B}}$ & $2.76 \pm 0.42^{\mathrm{A}}$ & $3.02 \pm 0.38^{\mathrm{A}}$ \\
\hline DTPN-2 & $1.08 \pm 0.45^{\mathrm{C}}$ & $1.49 \pm 0.41^{\mathrm{C}}$ & $2.22 \pm 0.36^{\mathrm{B}}$ & $2.54 \pm 0.35^{\text {B }}$ & $3.08 \pm 0.41^{\mathrm{A}}$ \\
\hline
\end{tabular}

CBN-2, DCPN-2 and DTPN-2: Chicken nuggets incorporated with $6 \%$ corn bran, $6 \%$ dried carrot pomace and $6 \%$ dried tomato pomace respectively; Means with different small superscripts within a column and capital superscripts within a row for a particular parameter differ significantly $(\mathrm{p} \leq 0.05)$. 
day, the SPC of all the treatments crossed the acceptability limit of $6 \log \mathrm{cfu} / \mathrm{g}$ making the products unacceptable.

\section{CONCLUSION}

Healthier chicken nuggets with better cooking yield and enriched with dietary fibre can be prepared by replacing chicken meat with $6 \%$ corn bran, $6 \%$ dried apple pomace and $6 \%$ dried carrot pomace individually. $100 \mathrm{~g}$ serving of each type of fibre enriched nugget can meet about $15 \%$ of daily requirement of dietary fibre.

\section{ACKNOWLEDGEMENTS}

Financial assistance provided by Ministry of Food Processing Industries, New Delhi, India is thankfully acknowledged.

\section{REFERENCES}

Alan, P.A., Ofelia, R.S., Patricia, T. and Rosario Maribel, R.S. 2012. Cereal bran and whole grain as a source of dietary fiber: Technological and health aspects. Int. J. Food Sci. Nutr., 63(7): 882-892.

Angelo, AJ St, Vercellotti, J.R., Legendre, M.G., Vinnett, C.H., Kuan, J.W., James, C. Jr. and Dupuy, H.P. 1987. Chemical instrument analyses of warmed over flavour in beef. $J$. Food Sci., 52: 1163-1168.

AOAC. 1995. Official Methods of Analysis, $16^{\text {th }}$ edition, Association of Official Analytical Chemists, Washington, DC.

AOAC. 1997. Official Methods of Analysis, 16th Edition, Volume II, Section 45.4.07, Method 985.29.

APHA. 1984. Recommended methods for microbiological examination of foods. Washington, DC.

Baliga, B.R. and Madaiah, N. 1970. Quality of sausage emulsion prepared from mutton. J. Food Sci., 35: 383-385.

Baljeet, S., Ritika, B. and Reena, K. 2014. Effect of incorporation of carrot pomace powder and germinated chickpea flour on the quality characteristics of biscuits. Int. Food Res. J., 21(1): 217-222.

Bauer, J.L., Harbaum-Piayda, B., Stockmann, H. and Schwarz, K. 2013. Antioxidant activities of corn fiber and wheat bran and derived extracts. J. Food Sci. Technol., 50(1): 132-138.

Bourne, M.C. 1978. Texture profile analysis. Food Technol., 33: 62-66, 72 .

Cava, Ramon, Luis Ladero, Cantero, V. and Rosario Ramırez, M. 2012. Assessment of different dietary fibers (Tomato Fiber,
Beet Root Fiber, and Inulin) for the manufacture of chopped cooked chicken products. J. Food Sci., 77(4): C346- C352.

Codex Alimentarius Commission. 2019. Codex alimentarius commission and report of the 30th session of the codex committee on nutrition and foods for special dietary uses. Retrieved June 7, 2019, from http://www. Codex alimentarius. net/download/ report/710/al32_26e .pdf.

Garcia Herrera, P., Sanchez-Mata, M.C. and Camara, M. 2010. Nutritional characterization of tomato fiber as a useful ingredient for food industry. Innov. Food Sci. Emerg., 11(4): 707-711.

Goncalves, E.M., Pinheiro, J., Abreu, M., Brandao, T.R.S. and Silva, C.L.M. 2010. Carrot (Daucus carota L.) peroxidase inactivation, phenolic content and physical changes kinetics due to blanching. J. Food Eng., 97(4): 574-581.

Grossi, A., Soltoft-Jensen, J., Knudsen, J.C., Christensen, M. and Orlien, V. 2011. Synergistic cooperation of high pressure and carrot dietary fibre on texture and colour of pork sausages. Meat Sci., 89: 195-201.

Kalogeropoulos, N., Chiou, A., Pyriochou, V., Peristeraki, A. and Karathanos, V.T. 2012. Bioactive phytochemicals in industrial tomatoes and their processing byproducts. $L W T$ Food Sci. Technol., 49(2): 213-216.

Kumar, D., Mehta, N., Chatli, M.K., Malav, O.P. and Kumar, P. 2019. Quality attributes of functional pork patties incorporated with kinnow (Citrus reticulata) pomace powder. J. Anim. Res., 9(3): 411-417.

Mehta, N., Ahlawat, S.S., Sharma, D.P. and Dabur, R.S. 2015. Novel trends in development of dietary fiber rich meat products-a critical review. J. Food Sci. Technol., 52(2): 633647.

Mehta, Nitin, Ahlawat, S.S., Sharma, D.P., Yadav, Sanjay and Arora, Devan. 2013. Sensory attributes of chicken meat rolls and patties incorporated with the combination levels of rice bran and psyllium husk. J. Anim. Res., 3(2): 179-185.

O'Shea, Norah, Arendt, Elke K. and Gallagher, Eimear 2012. Dietary fibre and phytochemical characteristics of fruit and vegetable by-products and their recent applications as novel ingredients in food products. Innov. Food Sci. Emerg., 16: $1-10$.

Parkash, J., Yadav, S., Sharma, D.P., Pathera, A.K. and Raut, S. 2016. Development of dietary fibre enriched chevon rolls by incorporating corn bran and dried apple pomace. J. Anim. Res., 6(4): 603-609.

Sharoba, A.M., Farrag, M.A. and Abd El-Salam, A.M. 2013. Utilization of some fruits and vegetables waste as a source of dietary fiber and its effect on the cake making and its quality attributes. J. Agroaliment. Proc. Technol., 19(4): 429-444. 
The Lancet. 2019. High intake of dietary fiber and whole grains associated with reduced risk of non-communicable diseases. Science Daily. Retrieved June 8, 2019 from www. science daily.com/releases/2019/01/190110184737.htm.

Trout, E.S., Hunt, M.C., Johson, D.E., Clans, J.R., Castner, C.L. and Kroff, D.H. 1992. Characteristics of low fat ground beef containing texture modifying ingredients. J. Food Sci., 57: 19-24.

Virtanen, H.E.K., Voutilainen, S., Koskinen, T.T., Mursu, J., Kokko, P., Ylilauri, M.P.T. and Virtanen, J.K. 2019. Dietary proteins and protein sources and risk of death: The Kuopio ischaemic heart disease risk factor study. Am. J. Clin. Nutr., 109(5): 1462-1471.
Witte, V.C., Krouze, G.F. and Bailey, M.E. 1970. Anew extraction method for determining 2-thiobarbituric acid values of pork and beef during storage. J. Food Sci., 35: 582-585.

Yadav, S., Malik, A, Pathera, A., Islam, R. and Sharma, D. 2016. Development of dietary fibre enriched chicken sausages by incorporating corn bran, dried apple pomace and dried tomato pomace. Nutr. Food Sci., 46(1): 16-29.

Zak, B. 1957. Simple rapid microtechnic for serum total cholesterol. Am. J. Clin. Pathol., 27: 583-588. 